\title{
Reproductive cycle of Glycymeris nummaria (Mollusca: Bivalvia) from Mali Ston Bay, Adriatic Sea, Croatia
}

\author{
MARIJA CRNČEVIĆ ${ }^{1}$, MELITA PEHARDA ${ }^{2}$, DARIA EZGETA-BALIĆ ${ }^{2}$ \\ and MARIJANA PEĆAREVIĆ ${ }^{3}$ \\ ${ }^{1}$ Public Institution for the Management of Protected Natural Values in the Dubrovnik-Neretva County, \\ Branitelja Dubrovnika 41, 20000 Dubrovnik, Croatia. \\ ${ }^{2}$ Institute of Oceanography and Fisheries, Šetalište Ivana Meštrovića 63, 21000 Split, Croatia. E-mail: melita@izor.hr \\ ${ }^{3}$ Department of Aquaculture, University of Dubrovnik, Cira Carića 4, 20000 Dubrovnik, Croatia.
}

\begin{abstract}
SUMMARY: The reproductive cycle of the dog cockle, Glycymeris nummaria (Glycymerididae), was studied using specimens collected monthly from Mali Ston Bay, southeastern Adriatic Sea over the period from January to December 2010. We analysed sex ratios, gonad developmental stages, and oocyte diameters using standard histological techniques. There were no differences in the overall sex ratio and no difference in shell length with respect to sex. Results of a size-frequency analysis of oocyte diameters agreed with a qualitative analysis of gonadal developmental stages, confirming the occurrence of one annual spawning peak from May to July. A significant correlation was identified between mean gonad indices of males and females and condition index. This study provides the first data on the reproductive characteristics of G. nummaria, providing necessary information for the future sustainable management of its potential fishery.
\end{abstract}

Keywords: reproduction, Bivalvia, Glycymeris nummaria, Adriatic.

RESUMEN: Ciclo reproductivo de Glycymeris nummaria (Mollusca: Bivalvia), de la bahía de Mali Ston, mar Adriático, CROACIA. - El ciclo reproductivo del bivalvo Glycymeris nummaria (Glycymerididae) fue estudiado en base a especímenes recolectados mensualmente entre enero y diciembre de 2012 en la Bahía Mali Ston (sudeste del Adriático). Analizamos la proporción sexual (sex ratio), los estadios del desarrollo gonadal y el diámetro de los ovocitos utilizando las técnicas histológicas estándares. No existen diferencias en la proporción sexual ni tampoco en la longitud de los especímenes en relación al sexo. Los resultados del análisis de la frecuencia de los diámetros de los ovocitos concordaron con el análisis cualitativo del estadio de desarrollo de las gónadas, confirmando la existencia de un pico de puesta anual entre los meses de mayo y julio. Asimismo se encontró una correlación significativa entre los índices gonadales promedio de machos y hembras y el índice de condición. Este estudio aporta por primera vez datos de las características reproductivas de G. nummaria que son necesarios para la gestión sostenible de la pesca potencial de esta especie en un futuro.

Palabras clave: reproducción, Bivalvia, Glycymeris nummaria, Adriático.

\section{INTRODUCTION}

Three species of Glycymerididae are known to occur in the Adriatic Sea, including Glycymeris bimaculata (Poli, 1795), G. glycymeris (Linnaeus, 1758) and G. nummaria (Linnaeus, 1758) (Legac and HrsBrenko 1999). Although data on their distributions and abundances in the Adriatic and Mediterranean Seas are provided in several publications (e.g. Legac and HrsBrenko 1999, Rinaldi 2002, Zenetos et al. 2005, Šiletić
2006, Dhora 2009, Manousis et al. 2010, Peharda et al. 2010), information on biology and ecology are limited, especially for G. nummaria. In the literature, the species is known by several synonyms including G. violacescens (Lamarck, 1819) and G. insumbrica (Brocchi, 1814).

Glycymeris nummaria is the smallest of the three species and usually attains shell lengths of up to $70 \mathrm{~mm}$ (Poppe and Goto 2000). It is considered to be mainly a Mediterranean species, but has also been recorded from 
the Atlantic, primarily from the area around Gibraltar (Poppe and Goto 2000). According to Legac and HrsBrenko (1999) G. nummaria prefers fine well-sorted sands and lives at depths ranging from 2 to $40 \mathrm{~m}$. Since this substratum type is relatively rare in the eastern Adriatic, G. nummaria is not considered a common species here. In locations where it is present, however, it can attain a density of $62 \mathrm{~g} / \mathrm{m}^{2}$ and an abundance of $1.59 \mathrm{ind} / \mathrm{m}^{2}$ (Peharda et al. 2010). A shell length of 50 $\mathrm{mm}$ is attained within 8 years and maximum longevity is estimated at 20 years (Peharda et al. 2012a).

In Croatia, G. nummaria presently has negligible commercial value, since it is used only occasionally for fish bait, souvenirs and only rarely for human consumption (Legac and Fabijanić 1994, Zavodnik 1997). In other parts of the Mediterranean, however, such as France, species of Glycymeris have a higher commercial value and are considered a delicacy (Le Bouteux 1992, Poppe and Goto 2000).

The aim of this study was to investigate the reproductive cycle and gonadal development of G. nummaria from Mali Ston Bay in the eastern Adriatic Sea. We combined the qualitative technique of gonadal stage analysis and quantitative measurements of oocyte diameter to determine the timing of reproductive development and spawning. We also analysed sex ratios and annual trends in mean gonad index and condition index. Due to its local abundance, it is possible that G. nummaria might become a fisheries object. Accordingly, the data obtained provide a basis for the sustainable management of natural populations.

\section{MATERIALS AND METHODS}

Sampling was conducted monthly in Mali Ston Bay (42 ${ }^{\circ} 52^{\prime} 17^{\prime}$ 'N, $1^{\circ} 39^{\prime} 08^{\prime}$ 'E) (Fig. 1). Samples were collected over the period from January to December 2010 using commercial SCUBA at depths of 4 to $7 \mathrm{~m}$. Seawater temperature data were obtained from Peharda et al. (2012b), who measured this parameter at a nearby location at $7 \mathrm{~m}$ depth $\left(42^{\circ} 51^{\prime} 45^{\prime}{ }^{\prime} \mathrm{N}, 17^{\circ} 40^{\prime} 59^{\prime}\right.$ 'E) using a hydrographic probe (YSI Professional Plus).

The reproductive cycle of $G$. nummaria was studied using 30 similar-sized individuals collected monthly, except in January 2010 when only 25 animals were obtained due to logistical problems with sample collection. The shell length of each individual was measured to the nearest $0.1 \mathrm{~mm}$ using Vernier calipers. Lengths of sampled individuals ranged from 50.0 to $75.1 \mathrm{~mm}$, with a mean value of $60.3 \pm 4.3 \mathrm{~mm}$.

The bivalves were opened within $3 \mathrm{~h}$ of collection with cuts through the adductor muscles and gonadal tissues were fixed in modified Davidson's solution. In the laboratory, tissues were dehydrated in increasing ethanol concentrations, embedded in Histowax (Leica), sectioned at $5 \mu \mathrm{m}$ and stained in haematoxylin and eosin. Sections were examined at 50x and 100x magnifications, sexed and assigned to a developmental stage (Walker and Power 2004), i.e. inactive (0), early active (3), late

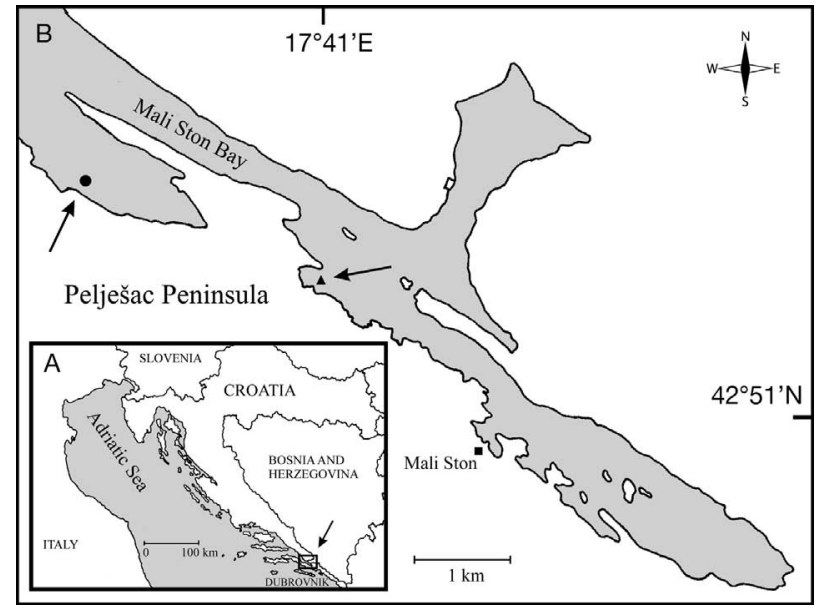

FIG. 1. - Map of the study area: A, position of Mali Ston Bay in the Adriatic Sea; B, map of the sampling location. Filled circle indicates location of the shell sampling site. Filled triangle indicates the location where temperature measurements were made.

active (4), ripe (5), partially spawned (2) and spent (1) (Fig. 2). A description of the gonad histological stages is given in Table 1. Mean gonad index (MGI) values were obtained by multiplying the number of individuals from each developmental stage by its numerical ranking, and dividing this by the number of individuals (Gosling 2003). The relationships between the MGI of males and females versus temperature were examined.

The size frequency distribution of oocyte diameters was studied using photographs of three visual fields of each histological section of the female gonads. Photographs were made with a Zeiss AxioCam ERc 5s using Axio Lab A1 microscope at 100x magnification $(\sim 0.60$ $\mathrm{mm}^{2}$ ). Oocyte diameter was measured using AxioVision Rel 4.8 software.

For condition index analysis, 25 individuals of $G$. nummaria were collected, except in January and June when only 23 and 22 animals were obtained, respectively. Individuals used for condition index analysis had a mean shell length of $55.7 \pm 3.2 \mathrm{~mm}$, with a range of 48.0 to $63.5 \mathrm{~mm}$. Field collected specimens were frozen. Prior to analysis, individuals were defrosted and cooked in boiling water for 5 min. Soft tissues were removed from the shell and both were left to air dry for one hour. Flesh and shell weights of each individual were obtained to the nearest $0.01 \mathrm{~g}$. Condition index was determined as the ratio between cooked meat weight and the sum of cooked meat weight and shell weight, according to Davenport and Chen (1987).

A chi-square test was applied for sex ratio analysis. Differences in shell length distribution with respect to sex and differences in condition index and sampling month were tested using ANOVA (MINITAB statistical package). Prior to this analysis, data were tested for homogeneity of variance using Levene's test and, if needed, log transformed. Pearson correlation analysis was applied to the datasets to determine the degree of association between MGI, condition index and seawater temperature. 
A

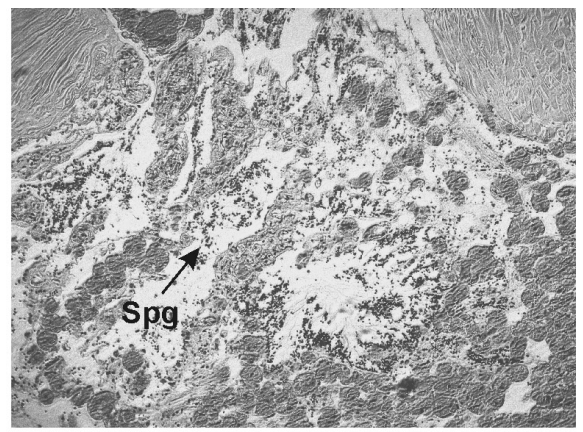

B

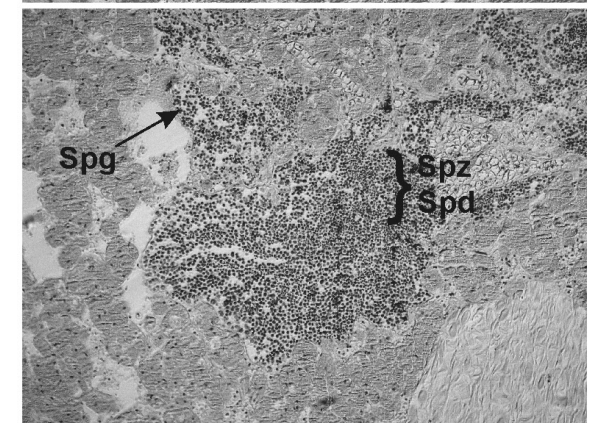

C

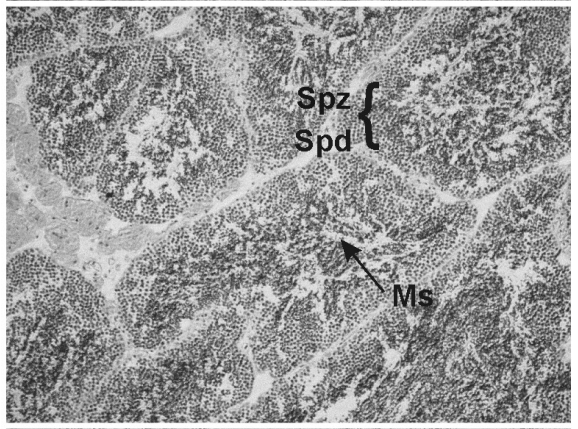

D

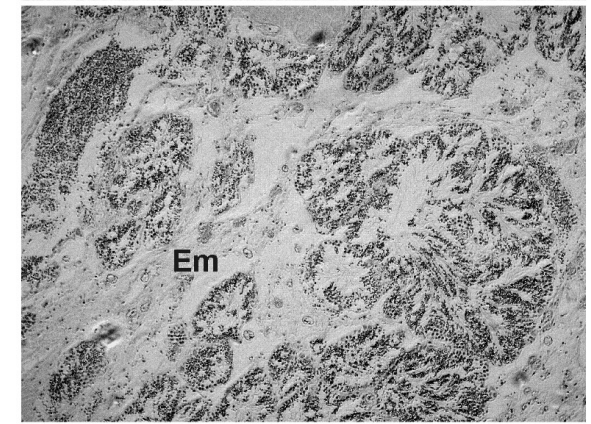

E

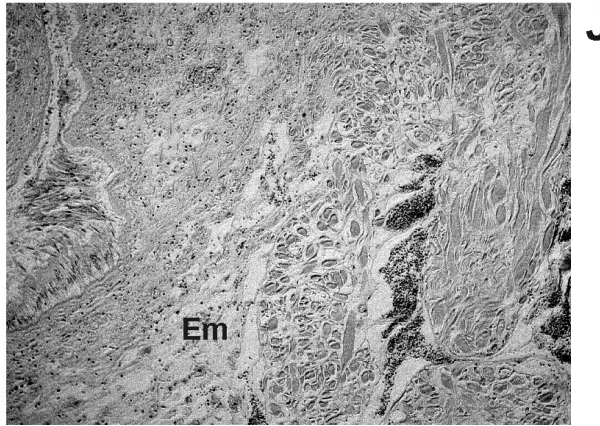

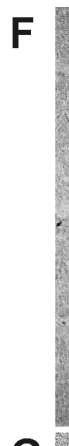

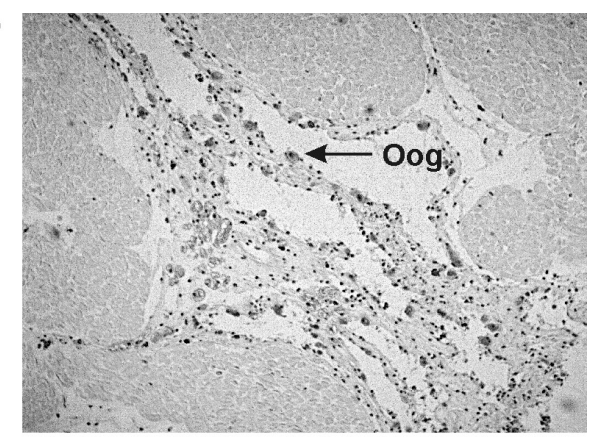

G

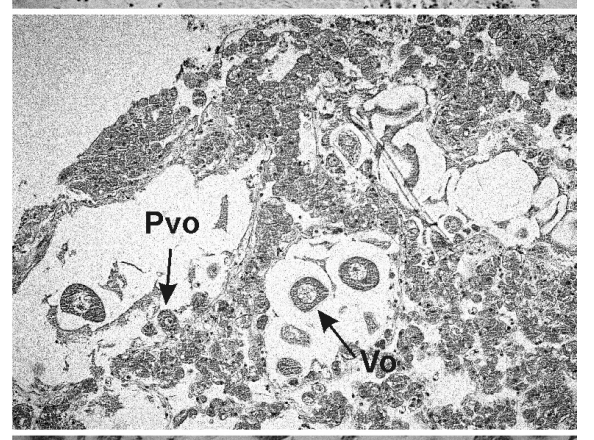

H
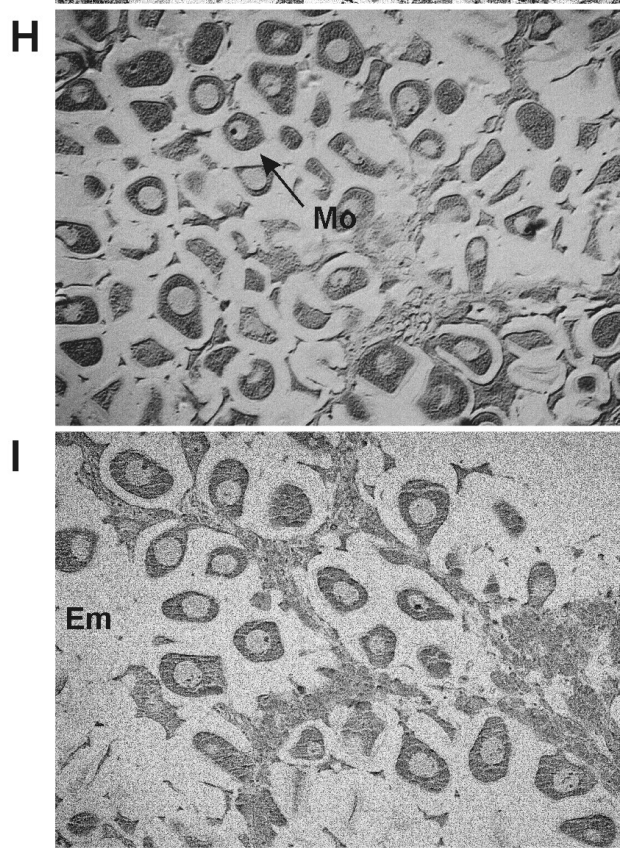

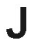

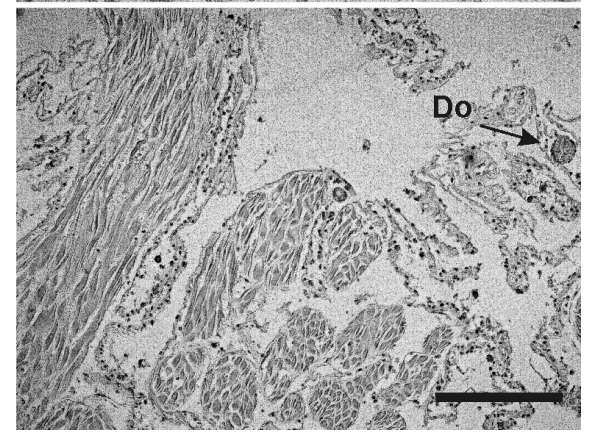

Fig. 2. - Light photomicrographs of the different histological gonadal stages of male Glycymeris nummaria (A) early active, (B) late active, (C) ripe, (D) partially spawned and (E) spent; and female individuals (F) early active, $(\mathrm{G})$ late active, $(\mathrm{H})$ ripe, (I) partially spawned and (J) spent. (Do, degenerative oocyte; Em, empty spaces; Mo, mature oocyte; Ms, mature spermatozoa; Oog, oogonia; Spz, spermatocytes; Spd, spermatids; Spg, spermatogonia; scale bar $200 \mu \mathrm{m})$. 
TABLE 1. - Histological appearance of six gonad stages in Glycymeris nummaria

\begin{tabular}{|c|c|c|}
\hline & Male & Female \\
\hline Inactive & Sex determination not possible. & Sex determination not possible. \\
\hline Early active & $\begin{array}{l}\text { Acini loose, with spread germinative cells } \\
\text { and spermatogonia. }\end{array}$ & $\begin{array}{l}\text { Oogonia attached basally to the follicle wall among } \\
\text { scarce non-differentiated germinative cells. }\end{array}$ \\
\hline Late active & $\begin{array}{l}\text { Larger more compact acini. A layer of developing } \\
\text { spermatogonia, spermatocytes and spermatids. }\end{array}$ & $\begin{array}{l}\text { Oogonia in lesser numbers attached to the follicle wall. } \\
\text { Large previtellogenic and few vitellogenic oocytes } \\
\text { located in the middle of the follicles. }\end{array}$ \\
\hline Ripe & $\begin{array}{l}\text { Layer of spermatocytes and spermatids located } \\
\text { on the periphery of the acini, lumina filled with } \\
\text { mature spermatozoa. }\end{array}$ & $\begin{array}{l}\text { Follicles rounded, large with attached and detached } \\
\text { mostly mature oocytes that are not tightly packed. }\end{array}$ \\
\hline Partially spawned & $\begin{array}{l}\text { Loose and abundant connective tissue surrounding } \\
\text { partially emptied acini, mainly filled with mature } \\
\text { spermatozoa. }\end{array}$ & $\begin{array}{l}\text { Gonadal regression, with loose and partially emptied } \\
\text { follicles. Mature oocytes detached. }\end{array}$ \\
\hline Spent & $\begin{array}{l}\text { Collapsed and emptied acini. } \\
\text { Remains of spermatozoa present. }\end{array}$ & Empty follicles with few degenerative oocytes. \\
\hline
\end{tabular}

\section{RESULTS}

It was not possible to determine sex for 52 individuals collected during the period from January to March and from September to December 2010 (Fig. 3). Mean length of these individuals was $59.5 \pm 3.8 \mathrm{~mm}$. There was no difference in sex ratio, as a total of 151 males and 152 females were determined from the histological slides (chi-square $=0.003, p=0.954$ ). Mean length of analysed males was $60.9 \pm 4.0 \mathrm{~mm}$, while that of females was $60.2 \pm 4.1 \mathrm{~mm}$. Only three individuals had a shell length $>70 \mathrm{~mm}$ and all were males. There was no statistically significant differences in the shell lengths of sexually undetermined individuals, males and females (ANOVA F=1.54, $\mathrm{p}=0.207$ ).

Analysis of qualitative stages of gonad maturation showed one reproductive peak per year. Gonadal ripening occurred from May to July for both males and females (Fig. 4). The percentages of mature males were $33 \%, 82 \%$ and $67 \%$ in May, June and July, respectively. Mature females were also obtained in only three sampling months and represented the majority of individuals (80\%) in July, whereas in May and June only $22 \%$ and $39 \%$ of females were mature, respectively. Spawning occurred in July and August, as all individuals collected in the latter month were either

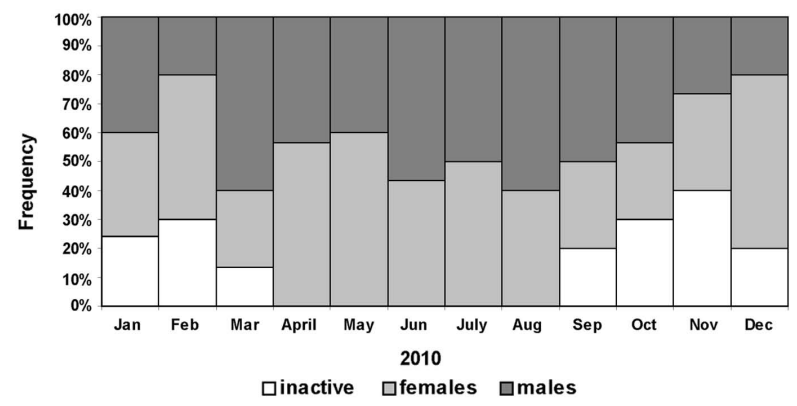

FIG. 3. - Frequencies of males, females and individuals for which it was not possible to determine sex, according to sampling month.
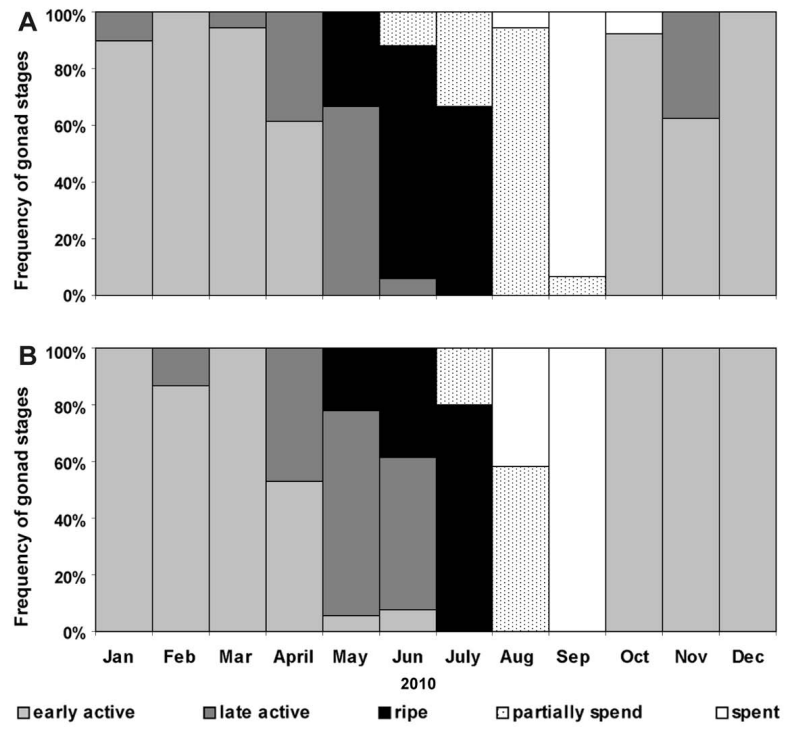

FIG. 4. - Glycymeris nummaria. The relative frequency of each development phase. A, males; B, females.

partially spawned or spent. In the months preceding May, analysed individuals were either in early or late active stages. In a significant proportion of the sampled individuals $(95 \%)$ gametogenesis had started in October and continued throughout the winter and spring months.

The frequency distributions of oocyte diameters according to sampling months are presented in Figure 5. Monthly mean oocyte diameter ranged from $9.20 \pm 2.75$ $\mu \mathrm{m}$ (October) to $41.93 \pm 23.65 \mu \mathrm{m}$ (July). The largest increase in mean monthly values of oocyte diameter occurred from June $(27.00 \pm 16.49 \mu \mathrm{m})$ to July. From May to August, the frequency distributions of oocyte diameters were polymodal and asymmetric, indicating female gametes in different developmental stages. The highest frequency of oocytes $>80 \mu \mathrm{m}$ was seen in July $(5.8 \%)$, whereas in June and August the frequency was 


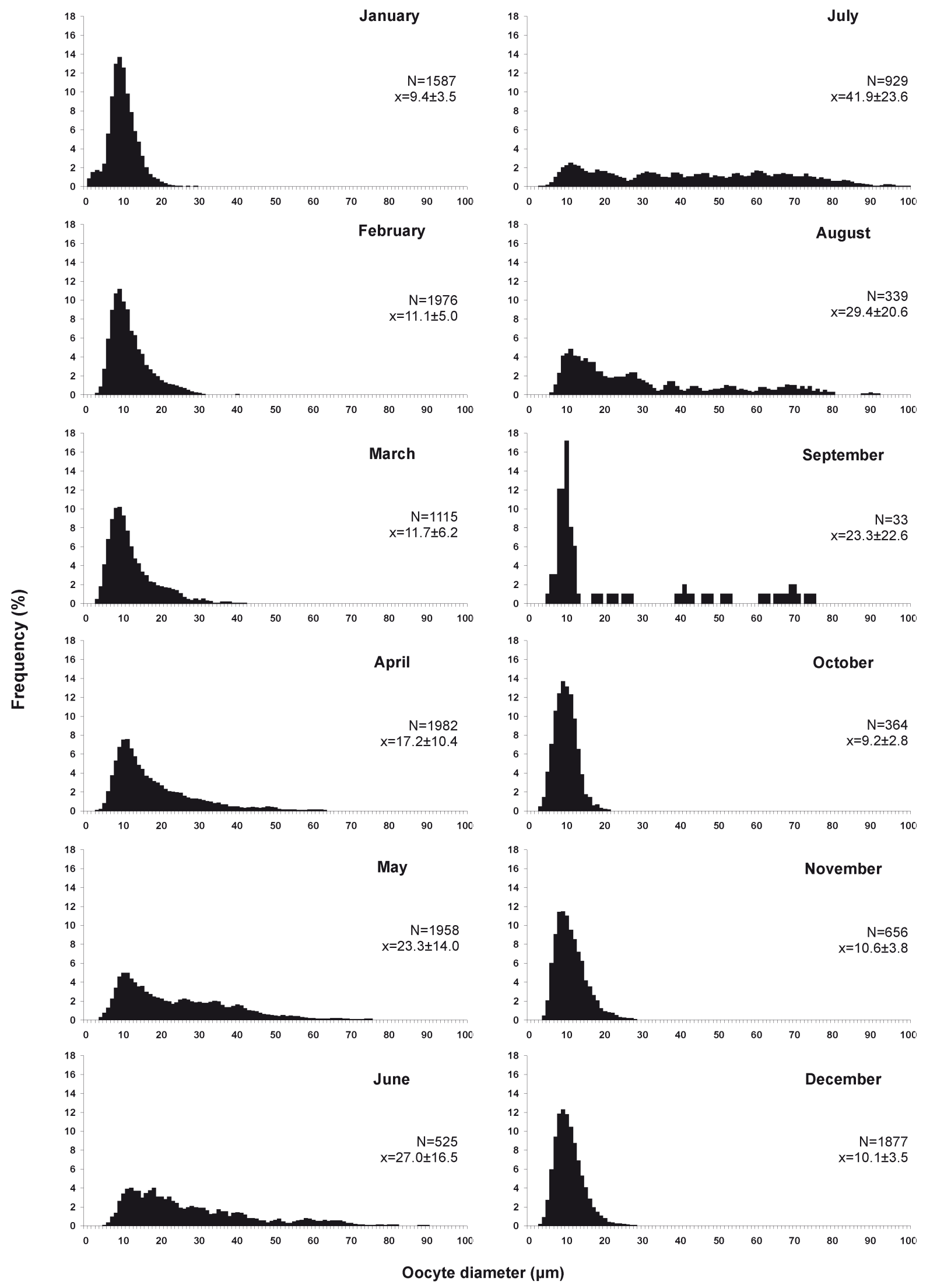

FIG. 5. - Size frequency histograms of oocyte diameters measured for female Glycymeris nummaria sampled each month. 

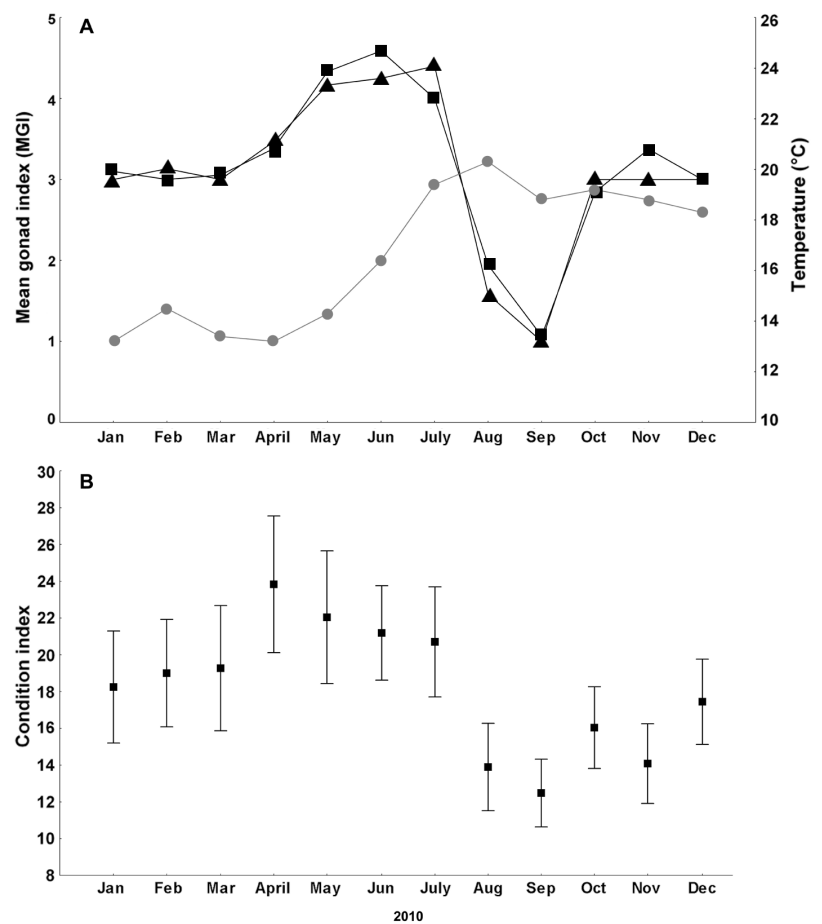

FIG. 6. - A, mean monthly gonad index values of males (squares), females (triangles) and seawater temperature (circles). B, mean monthly condition index and corresponding standard deviation for Glycymeris nummaria.

$<0.6 \%$. The frequency of oocytes $<20 \mu \mathrm{m}$ started to increase in August.

The highest MGI values were recorded from April to July for both sexes. The increase in MGI from May to July coincided with an increase in seawater temperature, while spawning, which occurred between the July and August, coincided with the highest annual temperatures (Fig. 6).

Mean monthly values of condition index of $>20$ were recorded between April to July, whereas over the period from August to November, values were $<17$. The highest mean monthly value of condition index was recorded in April (23.83 \pm 3.72$)$, while the lowest value was obtained in September (12.48 \pm 1.84$)$, representing a $48 \%$ reduction. A statistically significant difference was noted in log-transformed condition index values with respect to sampling month (ANOVA $\mathrm{F}=42.57, \mathrm{p}<0.001$ ). Condition index values followed closely those of MGI. There was thus a significant correlation between mean monthly condition index and MGI for males (Pearson $\mathrm{r}=0.774, \mathrm{p}=0.003$ ) and females (Pearson $\mathrm{r}=0.824, \mathrm{p}=0.001$ ), and a significant negative correlation between condition index and seawater temperature (Pearson $\mathrm{r}=-0.665, \mathrm{p}=0.018$ ).

\section{DISCUSSION}

Results of this study indicate that Glycymeris nummaria is dioecious, with equal numbers of adult male and female individuals present in the sampled population. Since the primary objective of this study was, however, to analyse the seasonal cycle of gonad maturation, it was conducted on similar-sized individuals and we can draw no definite conclusions with regard to small individuals. Previous studies that have analysed the size range of Glycymeris spp., including G. glycymeris (Lucas 1975), G. longior (G.B. Sowerby I, 1833; Ituarte 1979) and G. gigantea (Reeve, 1843; Villalejo-Fuerte et al. 1995), identified hermaphrodites and differences in sex ratios.

Bivalves are known to undergo an annual reproductive cycle that involves gametogenesis followed by either a single or several spawning events, which are in turn followed by a period of gonad reconstitution. The number of spawning events and duration of the spawning period can vary greatly with respect to species, geographic area and environmental conditions (Gosling 2003). Glycymeris nummaria investigated in this study had a single pronounced spawning event, as mature individuals were recorded only over the period from May to July. Several spawning peaks have previously been determined for populations of G. glycymeris from southern Brittany, France (Galap et al. 1997). Here, a period of vitellogenesis extended from February/March to April/May and preceded a spawning in spring. A second period of vitellogenesis extended from May/ June to September/October and led to no spawning, a single spawning event in autumn, or two spawning events in summer and autumn. A third period extended from October/November to February/March and was characterized by a high level of oocyte lysis (Galap et al. 1997). Steingrimsson (1989) recorded continuous reproductive activity by G. glycymeris, with developing and mature oocytes present year round. According to Villalejo-Fuerte et al. (1995), gametogenic activity of Glycymeris gigantea from Bahía Concepción (Mexico) occurred throughout the annual cycle with a notable spawning peak in autumn coinciding with a decline in temperature.

In the present study, empty spaces were identified in reproductive tissues of $G$. nummaria even in the ripe stage, and oocytes were never as tightly packed as in some other species such as Arca noae Linnaeus, 1758 (Peharda et al. 2006). According to Steingrimsson (1989), the main follicular volume of G. glycymeris was empty and oocytes never exceeded $30 \%$ of the available reproductive space. Steingrimsson (1989) provided two possible explanations for this. Firstly, that ripe oocytes are released before the follicles become packed with gametes and, secondly, that follicles are distended with the increase in gamete production.

In bivalves, oocyte size depends on the energy available and the reproductive strategy of the species, its life history, age, location and environmental stressors (Giese 1966, 1969, Honkoop and van der Meer 1998, Toro et al. 2002, Maloy et al. 2003, Meneghetti et al. 2004). Beninger and Le Pennec (1997) provided a review of maximum reported bivalve oocyte diameters 
and where variations with respect to species are clearly evident. They further demonstrated that Acharax alinae Métivier and Cosel 1993 has extraordinarily large male and female gametes and mature oocytes of $~ 600$ $\mu \mathrm{m}$. Mature oocytes of G. nummaria are smaller than those described for G. glycymeris and G. gigantea. In the present study, we recorded only a small percentage of oocytes $>80 \mu \mathrm{m}$. Analysis of oocyte diameter frequencies agree with the results of the quantitative analysis of gonad development. According to Lucas (1965 in Beninger and Le Pennec 1997), the maximum diameter of G. glycymeris oocytes is $\sim 170 \mu \mathrm{m}$, making them among the largest in bivalves. These are probably, however, extreme values as later studies point out that mature oocyte diameters of G. glycymeris were in the range 100 to $130 \mu \mathrm{m}$ (Steingrimsson 1989, Galap et al. 1997). Villalejo-Fuerte et al. (1995) reported oocytes of $G$. gigantea which were up to $150 \mu \mathrm{m}$ in diameter and which during the reproductive peak had a mean monthly diameter of $>120 \mu \mathrm{m}$.

Condition index in G. nummaria generally followed gonad development. In this study, an exception was a mean condition index value obtained for individuals collected in April, while the highest MGI values for males and females were obtained in June and July, respectively. A similar trend has been observed for Modiolus barbatus (Linnaeus, 1758), with the highest mean monthly condition index being recorded in May and the highest MGI occurring a few months later in August (Mladineo et al. 2007). Villalejo-Fuerte et al. (1995) noted that variations in G. gigantea condition index seemed to be influenced by gametogenic development, in accordance with our results.

Data on the reproductive characteristics obtained in this study show that in the Adriatic Sea G. nummaria has one spawning peak per year, which occurs during the summer months and that female and male gonad developments are synchronous. These results give an insight into the biology of G. nummaria and contribute to our understanding of species of Glycymerididae, some of whose members, such as G. glycymeris, are being considered as model organisms for reconstruction of environmental changes (Royer et al. 2013). Further studies should investigate size of individuals at sexual maturity, sex ratios with respect to shell length, fecundity and influence of environmental factors on the seasonal gonad cycle.

\section{ACKNOWLEDGEMENTS}

This research was financed by the Croatian Ministry of Science, Education and Sport. The authors would like to thank Maro Franušić, Nela Sinjkević and Margita Radman for their technical assistance during field research, Ivana Bušelić for assistance with figure preparation, Prof. Josep Lloret for the Spanish translation of the summary and Prof. Brian Morton for his useful suggestions, which significantly improved the quality of the manuscript.

\section{REFERENCES}

Beninger P.G., Le Pennec M. 1997. Reproductive characteristics of a primitive bivalve from deep-sea reducing environment: giant gametes and their significance in Acharax alinae (Cryptodonta: Solemydae). Mar. Ecol. Prog. Ser. 157: 195-206.

Davenport J., Chen X.G. 1987. A comparison of methods for the assessment of condition in the mussel (Mytilus edulis L.). J. Molluscan Stud. 53: 293-297.

Dhora D. 2009. Mollusks of Albania. Arch. Biol. Sci. 61: 537-553.

Galap C., Leboulenger F., Grillot J.P. 1997. Seasonal variations in biochemical constituents during the reproductive cycle of the female dog cockle Glycymeris glycymeris. Mar. Biol. 129: 625-634.

Giese A.C. 1966. Lipids in the economy of marine invertebrates. Physiol. Rev. 46: 244-298.

Giese A.C. 1969. A new approach to the biochemical composition of the mollusc body. Oceanogr. Mar. Biol. Annu. Rev. 7: 175-229.

Gosling E. 2003. Bivalve molluscs - biology, ecology and culture. Fishing News Books, Oxford, 443 pp.

Honkoop P.J.C., van der Meer J. 1998. Experimentally induced effects of water and temperature immersion time on reproductive output of bivalves in the Wadden Sea. J. Exp. Mar. Biol. Ecol. 220: $227-246$

Ituarte C.F. 1979. Sobre la sexualidad de Glycymeris longior (Sowerby) (Mollusca Pelecypoda). Neotropica 25: 161-165.

Le Bouteux F. 1992. Pêche maritime en Basse-Normandie: étude de 14 espèces en vue de leur utilisation industrielle prétransformation des produits de la pêche. Rapport Intechmer no. 9, 102 pp.

Legac M., Fabijanić I. 1994. Contribution to knowledge on the bivalve Glycymeris bimaculata (Poli, 1795) in Pag Bay. Period. Biol. 96: 450-51.

Legac M., Hrs-Brenko M. 1999. A review of bivalve species in the eastern Adriatic Sea. III. Pteriomorpha (Glycymerididae). Nat. Croat. 8: 9-25.

Lucas A. 1965. Recherches sur la sexualité des Mollusques Bivalves. Bull. Biol. Fr. Bel. 99: 115-247.

Lucas A. 1975. Sex differentiation and juvenile sexuality in bivalves Molluscs. P.S.Z.N.I. Mar. Ecol. 39: 532-541.

Maloy A.P., Barbera B.J., Rawson P.D. 2003. Gametogenesis in a sympatric population of blue mussels, Mytilus edulis and Mytilus trossulus, from Cobscook Bay, (USA). J. Shellfish Res. 22: 119-123.

Manousis T., Mpardakis G., Paraskevopoulos C., Galinou-Mitsoudi S. 2010. The Bivalvia Mollusca of Thessaloniki and Thermaikos Gulfs (North Aegean Sea, Greece) with emphasis on new species for Hellenic waters. J. Biol. Res-Thessalon. 14: 161-179.

Meneghetti F., Moschino V., Da Ros L. 2004. Gametogenic cycle and variations in oocyte size of Tapes philippinarum from the Lagoon of Venice. Aquaculture 240: 473-488.

Mladineo I., Peharda M., Orhanović S., Bolotin J., Pavela-Vrančić M., Treursić B. 2007. The reproductive cycle, condition index and biochemical composition of the horse-bearded mussel Modiolus barbatus. Helgoland Mar. Res. 61: 183-92.

Peharda M., Mladineo I., Bolotin J., Kekez L., Skaramuca B. 2006. The reproductive cycle and potential protandric development of the Noah's Ark shell, Arca noae L.: implications for aquaculture. Aquaculture 252: 317-327.

Peharda M., Ezgeta-Balić D., Vrgoč N., Isajlović I., Bogner D. 2010. Description of bivalve community structure in the Croatian part of the Adriatic Sea - hydraulic dredge survey. Acta Adriat. 51: 144-58.

Peharda M., Crnčević M., Bušelić I., Richardson C.A., Ezgeta-Balić D. 2012a. Growth and longevity of Glycymeris nummaria (Linnaeus, 1758) from the eastern Adriatic, Croatia. J. Shellfish Res. 31: 947-950.

Peharda M., Ezgeta-Balić D., Davenport J., Bojanić N., Vidjak O., Ninčević-Gladan Ž. 2012b. Differential ingestion of zooplankton by four species of bivalves (Mollusca) in the Mali Ston Bay, Croatia. Mar. Biol. 159: 881-895.

Poppe G.T., Goto Y. 2000. European seashells. Volume II. (Scaphopoda, Bivalvia, Cephalopoda). ConchBooks, Hackenheim, $221 \mathrm{pp}$.

Rinaldi E. 2002. Glycymeris (Glycymeris) insubrica (Brocchi, 1874) nelle acque antisanti la costa Romagnola (Mollusca Bivalvia Glycymerididae). Quad. Studi Nat. Romagna. 16: 15-20. 
Royer C., Thébault J., Chauvaud L., Olivier F. 2013. Structural analysis and paleoenvironmental potential of dog cockle shells (Glycymeris glycymeris) in Brittany, northwest France. Palaeogeogr. Palaeoclimatol. Palaeoecol. 373: 123-132.

Steingrimsson S.A. 1989. A comparative ecological study of two Glycymeris glycymeris $(L$.) populations off the Isle of Man. $\mathrm{PhD}$ thesis, Univ. Liverpool, $121 \mathrm{pp}$.

Šiletić T. 2006. Marine fauna of Mljet national park (Adriatic Sea), Croatia. 5. Mollusca: Bivalvia. Nat. Croat. 15: 109-169.

Toro J.E., Thompson R.J., Innes D.J. 2002. Reproductive isolation and reproductive output in two sympatric mussel species (Mytilus edulis, M. trossulus) and their hybrids from Newfoundland. Mar. Biol. 141: 897-909.

Villalejo-Fuerte M., García-Domínquez F., Ochoa-Báez R.I. 1995. Reproductive cycle of Glycymeris gigantea (Reeve, 1843) (Bivalvia: Glycymerididae) in Bahía concepción, Baja California
Sur, Mexico. Veliger 38: 126-132.

Walker R.L., Power A.J. 2004. Growth and gametogenic cycle of the transverse ark, Anadara transversa (Say, 1822), in coastal Georgia. Am. Malacol. Bull. 18: 55-60.

Zavodnik D. 1997. Nekonvencionalni izvori hrane iz mora na tržištu istočnog Jadrana. In: Finka B. (ed.), Tisuću godina prvog spomena ribarstva u Hrvata. HAZU, Zagreb, pp. 637-656. (in Croatian)

Zenetos A., Vardala-Theodorou E., Alexandrakis C. 2005. Update of the marine Bivalvia Mollusca checklist in Greek waters. $J$. Mar. Biol. Ass. U. K. 85: 993-998.

Scient. ed.: M. Ramon.

Received September 6, 2012. Accepted February 15, 2013.

Published online April 10, 2013. 